\title{
Prevalence And Contributing Factors Of Low Back Pain Among Nurses In Tertiary Level Hospital
}

\author{
Gautam GJ1, Gurung L2 , Shrestha N ${ }^{3}$, Shrestha PS ${ }^{4}$, Neupane $\mathbf{S}^{5}$ \\ 'Lecturer, Department of Anesthesiology, Gandaki Medical College Teaching Hospital \\ ${ }^{2}$ Critical Care Nurse and Research Coordinator, TUTH ICU \\ ${ }^{3}$ Lecturer, Department of Anesthesiology, TUTH, Consultant Pain Management \\ ${ }^{4}$ Lecturer, Department of Anesthesiology, Consultant Intensivist, TUTH ICU \\ ${ }^{5}$ Lecturer, Department Of Anesthesiology, Consultant Anesthesiologist, GMCTH
}

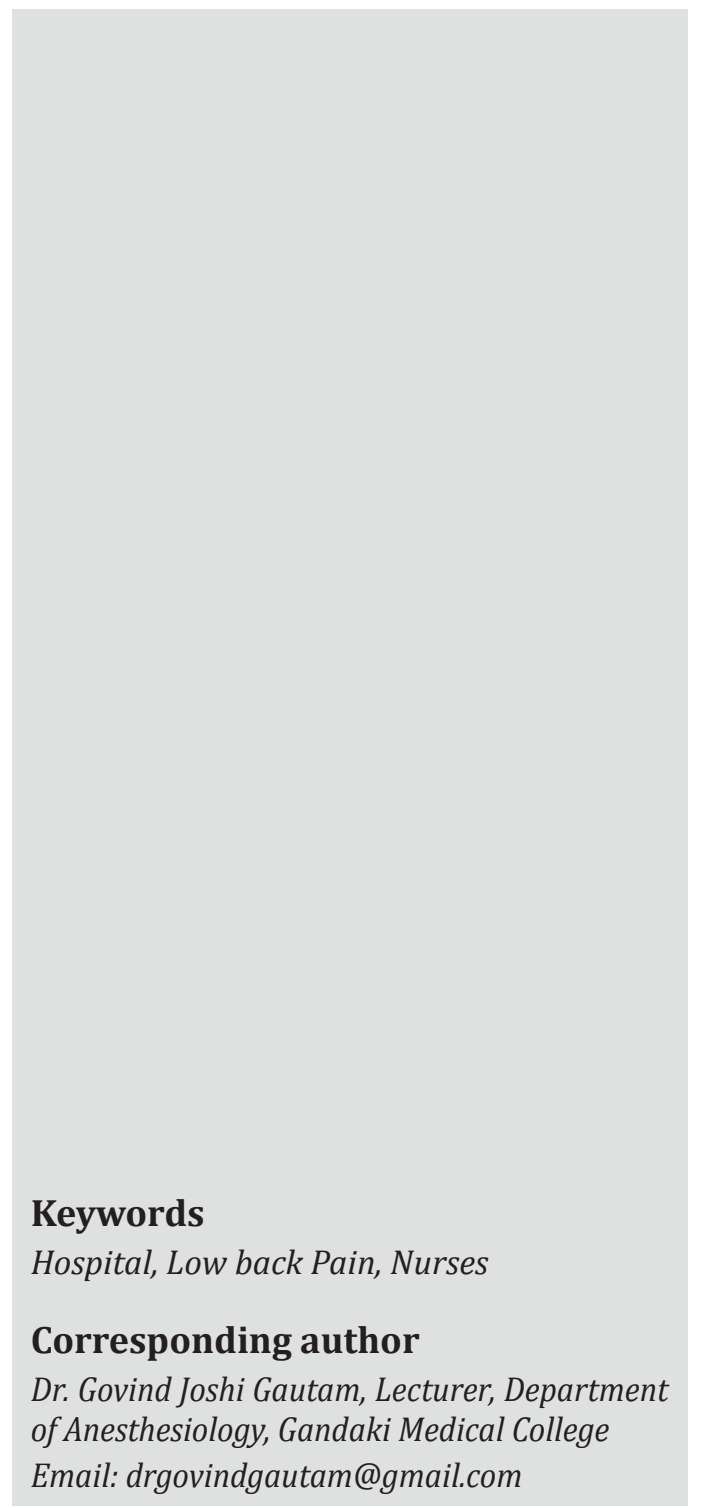

\begin{abstract}
Background: Low back pain is one of the common musculoskeletal health problems that occur most commonly in nurses among all Health workers. Different researches showed that nurses are suffering from low back pain due to many factors. This research was conducted to find the prevalence and contributing factors of low back pain among nurses.
\end{abstract}

Method: The descriptive cross-sectional study was done among 110 nurses by using stratified proportionate random sampling method. Semi structured self-administered questionnaire with single and multiple responses was administered among nurses after taking informed consent. Statistical package for social sciences (SPSS) 20 was used for analysis of data. Descriptive statistic (percentage and frequency) and inferential statistic (chi square) was used for the study.

Result: Among 110 nurses, $64.5 \%$ were affected from low back pain and prevalence of low back pain of one year and one week was $60 \%$ and $20 \%$ respectively. The present working area was strongly associated with low back pain $(\mathrm{p}=0.000)$. Prolong standing $(64.54 \%)$, bending and twisting (64.54\%), heavy workload (62.72\%), working in same positions (58.18\%) were perceived factors of low back pain but heavy mental workload had no relationship with low back pain. Taking rest (99.1\%), physiotherapy $(92.7 \%)$ and taking medication $(82.7 \%)$ were the factors that decreased low back pain. There was increased work restriction (46.4) and less productive and creative (42.7) due to low back pain.

Conclusion: More than half of nurses were affected from low back pain. Prolonged standing, physical workload, bending and twisting were main contributing factors. Therefore, it is recommended to maintain proper body mechanics, periodic screening and timely rotation of nurses for the prevention of low back pain.

\section{BACKGROUND}

International Association for the Study of Pain (IASP) defined pain as an unpleasant sensory and emotional experience associated with actual or potential tissue damage, or described in terms of such damage. The term low back pain (LBP) refers to pain in the lumbo-sacral area of the spine encompassing the distance from the first 
lumbar vertebra to the first sacral vertebra where the lordotic curve forms. The most frequent site of low back pain is in the 4 th and 5 th lumbar segment. It can be either acute, sub acute or chronic in onset duration. ${ }^{1}$ It occurs in similar proportions in all cultures, interferes with quality of life and work performance, and is the most common reason for medical consultation. ${ }^{2}$ Moreover, low back pain is said to be among the leading musculoskeletal disorders that predominantly affect the working population in developed as well as in developing countries. ${ }^{3}$

Seventy two percent (72\%) of Chinese hospital nurses experienced low back pain and nurses who reported manual handling of patients were 7.2 times more likely to report musculoskeletal symptoms. ${ }^{4}$ Sun et. al. also found out that the prevalence of low back pain was $87 \%$ in ICU nurses and 64\% in nurses working in other wards in a Chinese hospital study involving 4077 employees. ${ }^{5}$ There is high prevalence of low back pain among nurses working in tertiary hospital of South India. ${ }^{6}$

In the context of Nepal, there is high prevalence of nursing due to lifting, bending, awkward posture, long standing. ${ }^{8}$ In Nepal, there is limited research done in prevalence of low back pain among nurses and its impact among nurses

Thus we conducted this study with the objective to find out the prevalence and contributing factors of low back pain among nurses working in T.U. Teaching Hospital

\section{METHODOLOGY}

As the aim of this study was to find out the prevalence of LBP and contributing factors among the nurses, we chose a descriptive cross sectional study to determine the prevalence and contributing factors of Low Back Pain. The study site was Tribhuvan University Teaching Hospital at Maharajgunj, Kathmandu that is a tertiary level hospital and produces health manpower at various levels. We planned to conduct this study amongst more than 500 nurses working in different departments at TUTH.

Samples were selected from different wards proportionately on the basis of total population of nurses in selected area. Thus, four specialized units of TU Teaching Hospital namely Emergency (21.43\%, 24), ICU $(42.20 \%, 46)$, Operation theatre (O.T.) $(25.97 \%, 29)$ and Maternity (especially labour room) $(10.38 \%, 11)$ was chosen for the study.
A semi-structured questionnaire was developed to identify the prevalence, contributing factors of low back pain among nurses working in different departments of T.U.T.H and its impact in their daily life. Questionnaires based on following sections on the basis of objectives

An informed verbal consent was obtained from each respondent prior to data collection by explaining the purpose of the study. Ethical consideration was taken at the time of distributing questions and with Institutional Review Committee to ensure the right of the respondents.

The primary data was collected by providing selfadministered semi-structured questionnaire to nurses working in different area of Hospital. Stratified sampling was used. Nurses in each ward were collected by making different strata i.e. Emergency $(21.43 \%, 24)$, Maternity (especially labour room) $(10.38 \%, 11)$, Operation Theatre (O.T.) $(25.97 \%, 29)$ \& Intensive Care Unit (I.C.U.) (42.20\%, 46) according to number of nurses currently working in areas which were calculated by dividing total population in each ward by total population in specialized areas and obtained value was multiplied by total sample size (110). Equal portion of samples was further calculated by using random method in each stratum. Data collection was done within appropriate time of two weeks. Every precaution was taken to safeguard the Safety of right of participants. Semi structure questionnaire was used. Part of Nordic Questionnaires related to back pain was used to find out low back pain. Liker scale was be used to show nature of activities. Height was measured by using measuring tape and weight was calculated by using weighing machine. The collected data was checked for completeness of data, categorized data for coding and tabulated manually and stored safely and accurately. The tabulated data was interpreted by using descriptive statistics (percentage, frequency distribution, mean) and inferential statistics (chi-square) was used to show association between selected variables and low back pain and obtained $\mathrm{p}$ value. A confidence level of $95 \%$ was used during statistical analysis.

All the nurses with serious pathological disease e.g. tumors, tuber sclerosis etc., who had had other injuries within the past 12 months, for example sports injuries and motor vehicle accidents were excluded. Also, nurses who were pregnant, who had any history of obstetrical or gynecological surgery, who had less than 1 year experience or who were in leave during the collection period were excluded. 
The study was conducted with aim to find out prevalence and contributing factors of low back pain among nurses working in tertiary level hospital. The study was divided into two categories one related to socio-demographic variables and another related to low back pain to get answers of the research questions. SPSS 20 was used to do analysis of data.

\section{RESULTS}

The demographic data are presented in table 1 and prevalence of low back pain is presented in table 2 .

Table 1: Socio-Demographic Variables of the Respondents ( $\mathrm{n}=110$ )

\begin{tabular}{|c|c|c|}
\hline Demographic variables & Frequency & Percentage (\%) \\
\hline \multicolumn{3}{|l|}{ Age } \\
\hline 20-30 Years & 90 & 81.8 \\
\hline $31-40$ Years & 17 & 15.5 \\
\hline 41-50 Years & 3 & 2.7 \\
\hline \multicolumn{3}{|l|}{ B.M.I } \\
\hline Below 18, Underweight & 5 & 4.5 \\
\hline 18-24, Normal & 76 & 69.1 \\
\hline 24-30, Overweight & 29 & 26.4 \\
\hline \multicolumn{3}{|l|}{ Marital Status } \\
\hline Unmarried & 60 & 54.5 \\
\hline Married & 50 & 45.5 \\
\hline \multicolumn{3}{|l|}{ Educational Level } \\
\hline Certificate in Nursing & 46 & 41.8 \\
\hline Bachelor in Nursing & 64 & 58.2 \\
\hline \multicolumn{3}{|l|}{ Year of Employment } \\
\hline Less Than 5 Years & 66 & 60.0 \\
\hline 5-10 Years & 25 & 22.7 \\
\hline $10-15$ Years & 14 & 12.7 \\
\hline More Than 15 Years & 5 & 4.5 \\
\hline \multicolumn{3}{|l|}{ Present Working Area } \\
\hline Intensive Care Unit & 46 & 41.8 \\
\hline Operation Theatre & 29 & 26.4 \\
\hline Emergency & 24 & 21.8 \\
\hline Maternity & 11 & 10.0 \\
\hline \multicolumn{3}{|c|}{ Length of Stay in Present Area } \\
\hline 0-4 Years & 87 & 79.1 \\
\hline 4-8 Years & 17 & 15.5 \\
\hline 8-12 Years & 6 & 5.4 \\
\hline
\end{tabular}

Table 2: Prevalence of Low Back Pain ( $n=110)$

\begin{tabular}{lll}
\multicolumn{1}{c}{ Variables } & Frequency & $\begin{array}{c}\text { Percentage } \\
\text { (\%) }\end{array}$ \\
\hline Low Back Pain Prevalence & 71 & 64.5 \\
One Year LBP Prevalence & 66 & 60.0 \\
One Week LBP Prevalence & 22 & 20.0 \\
\hline
\end{tabular}

The table 2 revealed that the prevalence of low back pain among nurses working in tertiary hospital was $64.5 \%$. Table 2 revealed that the prevalence of low back pain among nurses during 12 months and during 7 days were $60 \%$ and $20 \%$ respectively. Thus from table 2, nurses working in T.U. Teaching Hospital were affected from low back pain.

Table 3: Duration of Low Back Pain in 12Months $(n=66)$

\begin{tabular}{lcc}
\hline $\begin{array}{l}\text { Duration of Low Back Pain in 12 } \\
\text { Months }\end{array}$ & Frequency & Percentage (\%) \\
\hline Every Day & 15 & 22.72 \\
1 Week & 37 & 56.06 \\
1 Month & 5 & 7.57 \\
More than One Month & 9 & 13.64 \\
\hline
\end{tabular}

The table 3 findings showed that 25.5\% respondents believed that low back pain did not disturb from doing normal activity and (40\%) believed that disturbance in clinical practice due to low back pain.

Table 3, explained about time prevented from doing work during last 12 months which was further categorized into every day, 1 week, 1 month and more than one month. Also, 81.39\% respondents were prevented from doing normal work for 1 week due to low back pain and $51.92 \%$ respondents said that they had pain in central area.

Table 4: Association between Demographic Variables and Low Back Pain (n=110)

\begin{tabular}{|cccc}
\hline Demographic Variables & $\begin{array}{c}\text { Had Low } \\
\text { Back } \\
\text { Pain }\end{array}$ & $\begin{array}{c}\text { Did not have low } \\
\text { back pain }\end{array}$ & p value $\left(^{*}\right.$ ) \\
\hline Age & 58 & 32 & 0.963 \\
$\quad<30$ Years & 13 & 7 & \\
$\quad>30$ Years & & & 0.081 \\
B.M.I & 50 & 31 & \\
$<24 \mathrm{~kg} / \mathrm{m}^{2}$ & 21 & 8 & 0.136 \\
$\quad>24 \mathrm{~kg} / \mathrm{m}^{2}$ & & & \\
Marital Status & 36 & 14 & \\
Married & 35 & 25 &
\end{tabular}




\begin{tabular}{lccc} 
Year of Employment & & & 0.149 \\
$\quad 0-10$ years & 56 & 35 & \\
$\quad 10-15$ Years & 15 & 4 & 0.000 \\
Present Working Area & & & \\
Intensive Care Unit & 37 & 9 & \\
Operation Theatre & 18 & 11 & \\
Emergency & 15 & 10 \\
Maternity & 1 & 9 \\
\hline
\end{tabular}

${ }^{*}$ chi square $\mathrm{p}$ value $<0.05$ is statistically significant

The result from table 4 shows that there is significant association between present working area and low back pain ( $p$ Value $=0.000$ ) but there was no association between other socio- demographic variables and low back pain.

Table 5: Nurse's Type of Activities ( $\mathrm{n}=110)$

\begin{tabular}{|c|c|c|c|c|}
\hline $\begin{array}{l}\text { Type of Activ- } \\
\text { ities }\end{array}$ & Never & $\begin{array}{l}\text { Some- } \\
\text { times }\end{array}$ & Often & Always \\
\hline $\begin{array}{l}\text { Moving Patient } \\
\text { in Different Posi- } \\
\text { tions }\end{array}$ & $11(10.0 \%)$ & $28(25.5 \%)$ & $28(25.5 \%)$ & $43(39.1 \%$ \\
\hline $\begin{array}{l}\text { Assisting in Am- } \\
\text { bulation }\end{array}$ & 18(16.4\%) & $42(38.2 \%)$ & $30(27.3 \%)$ & $20(18.2 \%$ \\
\hline Performing CPR & $24(21.8 \%)$ & $42(38.2 \%)$ & $33(30 \%)$ & $11(10 \%)$ \\
\hline Bed Making & $29(26.4 \%)$ & $23(20.9 \%)$ & $14(12.7 \%)$ & $44(40 \%)$ \\
\hline $\begin{array}{l}\text { Lifting and } \\
\text { Transferring } \mathrm{Pa}- \\
\text { tients }\end{array}$ & $7(6.4 \%)$ & $22(20 \%)$ & $25(22.7 \%)$ & $55(50 \%)$ \\
\hline Medications & $11(10 \%)$ & $20(18.2 \%)$ & $4(3.6 \%)$ & $75(68.2 \%)$ \\
\hline Dressing & $15(13.6 \%)$ & $34(30.9 \%)$ & $23(20.9 \%)$ & $38(34.5 \%$ \\
\hline $\begin{array}{l}\text { Providing Total } \\
\text { Care to Patients }\end{array}$ & $15(13.6 \%)$ & $27(24.5 \%)$ & $11(10 \%)$ & $57(51.8 \%$ \\
\hline
\end{tabular}

Table 6: Relationship between Severity of Pain and Absent from Work due to Low Back Pain (n=65)

\begin{tabular}{cccc}
\hline $\begin{array}{c}\text { Severity of } \\
\text { pain }\end{array}$ & $\begin{array}{c}\text { Absent from } \\
\text { Work }\end{array}$ & Present on Work & $\begin{array}{c}\text { p val- } \\
\text { ue(*) }\end{array}$ \\
\hline $\begin{array}{c}\text { Moderate } \\
\text { Pain }\end{array}$ & 9 & 18 & 0.001 \\
Mild pain & 5 & 33 & \\
\hline
\end{tabular}

*chi square $\mathrm{p}$ value $<_{-} 0.05$ is statistically significant value

Table 6, explained about association between severity of pain and leave taken due to low back pain. The findings showed that there was strongly association between severities of pain and absent from work due to low back pain.
Table 7: Lost Working Days ( $\mathrm{n}=19)$

\begin{tabular}{ccc}
\hline Lost Working Days & Frequency & Percentage \\
\hline 1-7 days & 14 & 12.7 \\
$7-15$ days & 5 & 4.5 \\
\hline
\end{tabular}

Table 7, explained about days taken leave due to low back pain. The findings showed that $12.7 \%$ respondents who had low back pain took leave for 1-7 days

The study reveals that majority of respondents believed that prolonged standing (98.2\%) was the major causes of low back pain followed by physical workload (97.3\%) and lifting patients (94.3\%) respectively. Similarly taking rest (99.1\%) during pain helped them to get relief from pain, which was followed by physiotherapy $(92.7 \%)$.

The result also showed that there was increased work restriction (46.4\%) due to low back pain. The findings also showed that in the opinion of respondents, follow good posture $(98.2 \%)$ was necessary to decrease low back pain.

\section{DISCUSSION}

Out of 110 participants of the study, majority of the participants were age of 20-30 years and $69.1 \%$ participants have normal BMI and there was equal proportion of married and unmarried nurses. More than half (58.2\%) of nurse participants had passed bachelor in nursing and $60 \%$ participants had work experience less than five years. Most of the nurses (79.1\%) were working in present area for less than four years. According to units, $41.8 \%$ participants were taken from I.C.U. followed by operation theatre $(26.4 \%)$, emergency $(21.8 \%)$ and maternity (10\%).

The prevalence of low back pain among nurses in our study is $64.5 \%$. This result was consistent with that of Shrestha et al, and Jensen et al..$^{8,9}$ Ajeesh et al. found that prevalence of low back pain were $65 \%$ and $70.6 \%$ respectively while the prevalence of low back pain among nurses in Japan was $54.7 \% .^{10}$ This may due to use of advanced technologies in handling patient and lower nurse patient ratio. This was contrast with the prevalence of low back pain among dentists conducted in Nepal and prevalence of low back pain among home makers conducted in Bangladesh were 52.4\% and 58.6\% respectively. ${ }^{11}$ This might be due to difference in work 
activities. In this study, the prevalence of low back pain among nurses during last 12 months and last 7 days were $60 \%$ and $20 \%$ respectively. This result was inconsistent with that of study by Kumalo et al. in which twelve months prevalence was $21 \%$ and last seven days prevalence was $47 \%{ }^{12}$ This study showed that prevalence of low back pain during last seven days was less than that during twelve 12 months and this was consistent with Tinubu et al. ${ }^{13}$ The longer duration of time having low back pain during last 12 months was one week.

In our study, there was no association between age, level of experience, and low back pain ( $\mathrm{p}$ value $=0.9$ and $\mathrm{p}$ value $=0.149$ ) that was supported by Lela and Frantz in Kanombe Military Hospital, Africa where there was no association between age, level of experience, and low back pain..$^{14}$ Aljeesh \& Al Nawajha ${ }^{10}$ also showed that there was no association between B.M.I and low back pain.

In our study, there was no association between marital status and low back pain ( $p$ value $=0.136$ ) that was in contrast to study by Lela \& Frantz (2013) where there was association between marital status and low back pain (p value $=0.020$ ). ${ }^{14}$ Also, in our study, there was strong association between present working area and low back pain which was inconsistent with the study by Lela \& Frantz. ${ }^{14}$

According to the unit placement, our results shows that the highest number of low back pain was among nurses working in ICU(37\%), followed by operation theatre(18\%) and least number was in the maternity ward (1\%). This may be related to the various and regular manual work in ICU nurses in feeding, positioning and mobilizing patients but these findings are not similar to by Mugga et al. ${ }^{15}$ in which only $12.8 \%$ nurses working in ICU had low back pain.

In this study, result showed that among the nurses who had LBP, $24.5 \%$ nurses complained that the exact area of pain was central followed by radiated to lower limbs (14.5\%) and radiated to buttocks (8.2\%). This was in agreement with a study by Wong et al. ${ }^{16}$ who reported that $64.2 \%$ had central and $35.8 \%$ complained of low back pain radiated to lower limbs.

The study also showed that prolonged standing (64.54\%), frequent bending and twisting (64.54\%), heavy workload (62.72\%), working in same positions for long period (58.18\%) s and lifting heavy load patients (55.45\%) were the most perceived causing low back pain among nurses. These findings of the study were similar to that of study by Aljeesh \& Al Nawajha ${ }^{10}$ who reported that prolonged standing (67.1\%), lifting and transferring patients (62.90\%), bending and twisting $(58.70 \%)$ were major contributing factors of low back pain but was inconsistent with that of Wong et. al. ${ }^{16}$ who found that $87.4 \%$ of nurses had LBP as a result of lifting heavy. Heavy mental workload was least contributing factors of the low back pain in the study which was in accordance with the study conducted by Mehrdad et. al. who reported that musculoskeletal symptoms were most associated with psychological factors especially stress and $71.9 \%$ participant experienced stressful working environment. ${ }^{17}$ The study concluded that findings of the study showed that $99.1 \%$ respondents believed that low back pain was relieved by rest followed by physiotherapy $(92.7 \%)$ and taking medication $(82.7 \%)$ This result was in agreement with the study of Bejia, et al. who found that $70 \%$ improved with the rest. ${ }^{18}$

There is negative effect among nurses due to low back pain in their performance. According to the findings of the study, the negative effects were increased work restriction (46.4\%), less productive and creative $(42.7 \%)$, not perform job properly $(40.0 \%)$, decrease my organizational commitment (33.6\%) and decreasing interpersonal relation with patients $(30 \%)$ which was supported by study conducted by Letvak S. et. al. ${ }^{19}$ in North Carolina in 2012 who reported that low back pain had effect on work restriction (64.3\%).

Low back pain has negative impact in the health and life of nurses. This will ultimately lead to decrease in quality of nursing services and jeopardizing patient care and leading to shortage of nurses. Thus respondents suggested some ways to decrease and prevent low back pain. The findings showed that follow good posture (98.2\%), rotation to staffs time to time (93.6\%) to different wards, use of automatic beds for patient positioning and proper maintenance equipment (91.8\%), decrease workload (91.8\%), performing exercise $(90.0 \%)$, in service education (88.2\%) and availability of assisted devices like belt, knee cap, chair with back rest (88.2\%) and improves quality of life of nurses.

However there were some limitations of this study including time limitation of the study, single center and small sample size. 


\section{CONCLUSIONS}

Low back pain is the common problems among health professionals' especially nurses and has strong association with current working unit (area) with prolonged standing, frequent bending and twisting, heavy workload and working in the same position for long periods being the most perceived risk factors. Low back pain also had negative effect in their work performance and thus recommended to nurses to use proper body mechanics during patient care and also recommended to institutions to rotate nursing staffs to various wards every few years to avoid mechanical stress and low back pain in nurses.

\section{REFERENCES}

1. Al-samawi MA, Awad HM. Incidences of Low Back Pain among Nurses Working in Elmak Nimer University Hospital-Shendi-Sudan 2015. Nursing and Health. 2015 Dec;3(6):129-38.

2. Keriri H. Prevalence and risk factors of low back pain among nurses in operating rooms, Taif, Saudi Arabia. Am J Res Commun. 2013;1(11):25.

3. Roffey DM, Wai EK, Bishop P, Kwon BK, Dagenais S. Causal assessment of occupational sitting and low back pain: results of a systematic review. The Spine Journal. 2010 Mar 1;10(3):252-61.

4. Smith DR, Wei N, Kang L, Wang RS. Musculoskeletal disorders among professional nurses in mainland China. Journal of Professional Nursing. 2004 Nov 1;20(6):390-5.

5. Sun J, He Z, Wang S. Prevalence and risk factors of occupational low back pain in ICU nurses. Zhonghua lao dong wei sheng zhi ye bing za zhi= Zhonghua laodong weisheng zhiyebing zazhi $=$ Chinese journal of industrial hygiene and occupational diseases. 2007 Aug;25(8):453-5.

6. Emmanuel NM, Ezhilarasu P, Bheemarao AB. Low back pain among nurses in a Tertiary Hospital, South India. Journal of Osteoporosis and Physical Activity. 2015 Nov 5;4(1):1-3.

7. Adhikari CM, Prajapati D, Baniya B, Regmi S, Bogati A, Thapaliya S. Prevalence of
Conventional Risk Factors in ST Segment Elevation Myocardial Infarction Patients in Shahid Gangalal National Heart Centre, Nepal. J Nepal Med Assoc. 2014 Jul 1;52(195):914-9.

8. Shrestha BP, Niraula S, Khanal GP, Karn NK, Chaudhary P, Rijal R, et al. Epidemiology of back pain in the teaching districts of BP Koirala Institute of Health Sciences. Health Renaissance. 2011;9(3):152-6.

9. Smedley J, Egger P, Cooper C, Coggon D. Prospective cohort study of predictors of incident low back pain in nurses. BMJ. 1997 Apr 26;314(7089):1225.

10. Aljeesh YI, Nawajha SA. Determinants of low back pain among operating room nurses in gaza governmental hospitals. Determinants of low back pain among operating room nurses in gaza governmental hospitals. 2011;14.

11. Acharya RS, Acharya S, Pradhan A, Oraibi S. Musculoskeletal disorders among dentists in Nepal. Journal of Nepal Dental Association. 2010;11(2):107-13.

12. Kumalo BT. The relationship between work-related musculoskeletal disorders, absenteeism and visits to the staff clinic by nurses in an eThekwini District hospital. [Thesis on the internet] [cited date - 2019 July 21, 2019]. https://openscholar.dut.ac.za/ handle/10321/1255.

13. Tinubu BM, Mbada CE, Oyeyemi AL, Fabunmi AA. Work-related musculoskeletal disorders among nurses in Ibadan, South-west Nigeria: a cross-sectional survey. BMC Musculoskeletal disorders. 2010 Dec;11(1):12.

14. Lela M, Frantz JM. Physical activity among nurses in Kanombe Military Hospital. African Journal of Physiotherapy and Rehabilitation Sciences. 2012;4(1-2):63-6.

15. Mugga JA. Analysis of Musculoskeletal Disorders amongst Nurses: a case study of Kenyatta National Hospital . [Thesis on the internet] [cited date - 2019 July 21, 2019]. Available from: 
Original Article | Journal of Gandaki Medical College-Nepal

http://ir.jkuat.ac.ke/handle/123456789/1224.

16. Wong TS, Teo N, Kyaw M. Prevalence and risk factors associated with low back among health care providers in a District Hospital. Malaysian Orthopaedic Journal. 2010;4(2):23-8.

17. Mehrdad R, Morshedizadeh M. Musculoskeletal disorders and ergonomic hazards among Iranian physicians. Archives of Iranian medicine. 2012 Jun 1;15(6):370.

18. Bejia I, Younes M, Jamila HB, Khalfallah T, Salem KB, Touzi M, Akrout M, Bergaoui N. Prevalence and factors associated to low back pain among hospital staff. Joint Bone Spine. 2005 May 1;72(3):254-9.

19. Letvak SA, Ruhm CJ, Gupta SN. Nurses' presenteeism and its effects on self-reported quality of care and costs. AJN The American Journal of Nursing. 2012 Feb 1;112(2):30-8. 